\title{
Chigger mites of the genus Eutrombicula Ewing, 1938 (Acari: Trombiculidae) from Cuba, with the description of three new species
}

\author{
Milan Daniel $^{1}$ and Alexandr A. Stekol'nikov ${ }^{2}$ \\ ${ }^{1}$ School of Public Health, Institute for Postgraduate Medical Education, Ruská 85, 10005 Prague 10, Czech Republic; \\ ${ }^{2}$ Zoological Institute, Russian Academy of Sciences, Universitetskaya 1, Saint-Petersburg 199034, Russia
}

Key words: Acari, chiggers, Eutrombicula, taxonomy, parasites, Cuba

\begin{abstract}
Three new species of chigger mites, Eutrombicula cubensis sp. n. and E. anguliscuta sp. n. from lizards and bats, and E. leiocephali sp. n. from lizards, are described. One species, E. lipovskyana (Wolfenbarger, 1953), is recorded for the first time in Cuba. Data on distribution of E. alfreddugesi (Oudemans, 1910) in Cuba are reported.
\end{abstract}

The genus Eutrombicula Ewing, 1938 including nearly 80 species is distributed mainly in the Western Hemisphere. Several species were reported as having medical and veterinary importance. The last revision of the genus Eutrombicula was presented by Loomis and Wrenn (1984) briefly and classified the known species into six groups involving 30 unnamed species. Therefore, further taxonomic investigations and descriptions of new Eutrombicula species are urgently needed, especially in northern South America where the Eutrombicula fauna is abundant.

Only one species of the genus Eutrombicula, E. alfreddugesi was previously reported from Cuba. In the present paper five Eutrombicula species including three new to science are described.

\section{MATERIALS AND METHODS}

The chiggers were collected by the group of Czech and Cuban zoologists individually mentioned in the paper by de la Cruz and Daniel (1994). Hosts were determined by Drs. O.H. Garrido (reptiles and birds) and G. Silva-Taboada (bats). Mites were mounted in Hoyer's medium or in de FaureBerlese's medium. All measurements are given in micrometres $(\mu \mathrm{m})$. Terminology follows Goff et al. (1982), with some adaptation: "ventral setae" (V) - setae on the ventral surface of idiosoma excluding coxal and sternal setae; VS number of ventral setae; D - dorsal idiosomal setae; DS number of dorsal idiosomal and humeral setae; TaIII - length of leg III tarsus; TaW - width of leg III tarsus; $\mathrm{m}-\mathrm{t}$ - ratio between distance from mastitarsala to the base of leg III tarsus and length of leg III tarsus. Type specimens are deposited in the acarological collections of the Zoological Institute of the Russian Academy of Sciences, Saint-Petersburg (ZIN), the Institute of Parasitology, Academy of Sciences of the Czech Republic, České Budějovice (PaÚ) and in the collection of the senior author.

\section{RESULTS}

Eutrombicula cubensis sp. n.

Figs. 1-11

Diagnosis. SIF $=7 \mathrm{BS}-\mathrm{N}-2-3111.1000 ; \mathrm{fPp}=\mathrm{B} / \mathrm{N} /$ $\mathrm{NNB} ; \mathrm{fCx}=1.1 .1 ; \mathrm{fSt}=2.2 ; \mathrm{fSc}: \mathrm{PL}>\mathrm{AL}=\mathrm{AM} ; \mathrm{Ip}=$ 747 ;D $=2$ H-6-6-6-2; fV = 6-2-2-2; $\mathrm{DS}=22 ; \mathrm{VS}=12$; $\mathrm{NDV}=34$.

Description. LARVA. Idiosoma. Eyes 2+2. One pair of humeral setae; 20 dorsal idiosomal setae, arranged 6$6-6-2$ (6-6-4-4); 2 pairs of sternal setae and 12 ventral setae, arranged 6-2-2-2; total idiosomal setae 34. Gnathosoma. Cheliceral blade with tricuspid cap; cheliceral base with dense small puncta in basal part and sparse large puncta in middle portion; gnathobase with sparse puncta and transverse striations, bearing a pair of branched setae; palpal femur and genu sparsely punctate; galeala nude; palpal claw with 2 equal prongs; seta on palpal femur branched; seta on palpal genu nude; dorsal and lateral palpal tibial setae nude, ventral palpal tibial seta with few branches; palpal tarsus with strongly branched dorsal seta, 6 weakly branched ventral and lateral setae, nude subterminala and tarsala. Scutum. Nearly rectangular, with rounded posterior margin, sparse moderate puncta, and indistinct transverse striations; AM base on level of ALs; SB anterior to level of PLs; $\mathrm{PL}>\mathrm{AL}=\mathrm{AM}$; sensilla flagelliform with 7-8 branches in distal half. Legs. All 7-segmented, with a pair of claws and clawlike empodium. Leg I: coxa with 1 non-specialised branched seta $(1 \mathrm{~B})$; trochanter $1 \mathrm{~B}$; basifemur $1 \mathrm{~B}$; telofemur $5 \mathrm{~B}$; genu 4B, 3 genualae, microgenuala; tibia 8B, 2 tibialae, microtibiala; tarsus 22B, tarsala 19-22 (20) long, microtarsala, subterminala, parasubterminala, pretarsala. Leg II: coxa 1B; trochanter $1 \mathrm{~B}$; basifemur $2 \mathrm{~B}$; telofemur $4 \mathrm{~B}$; genu $3 \mathrm{~B}$, genuala; tibia 6B, 2 tibialae; tarsus $16 \mathrm{~B}$, tarsala 13-14 (13) long, microtarsala, pretarsala. Leg III: 


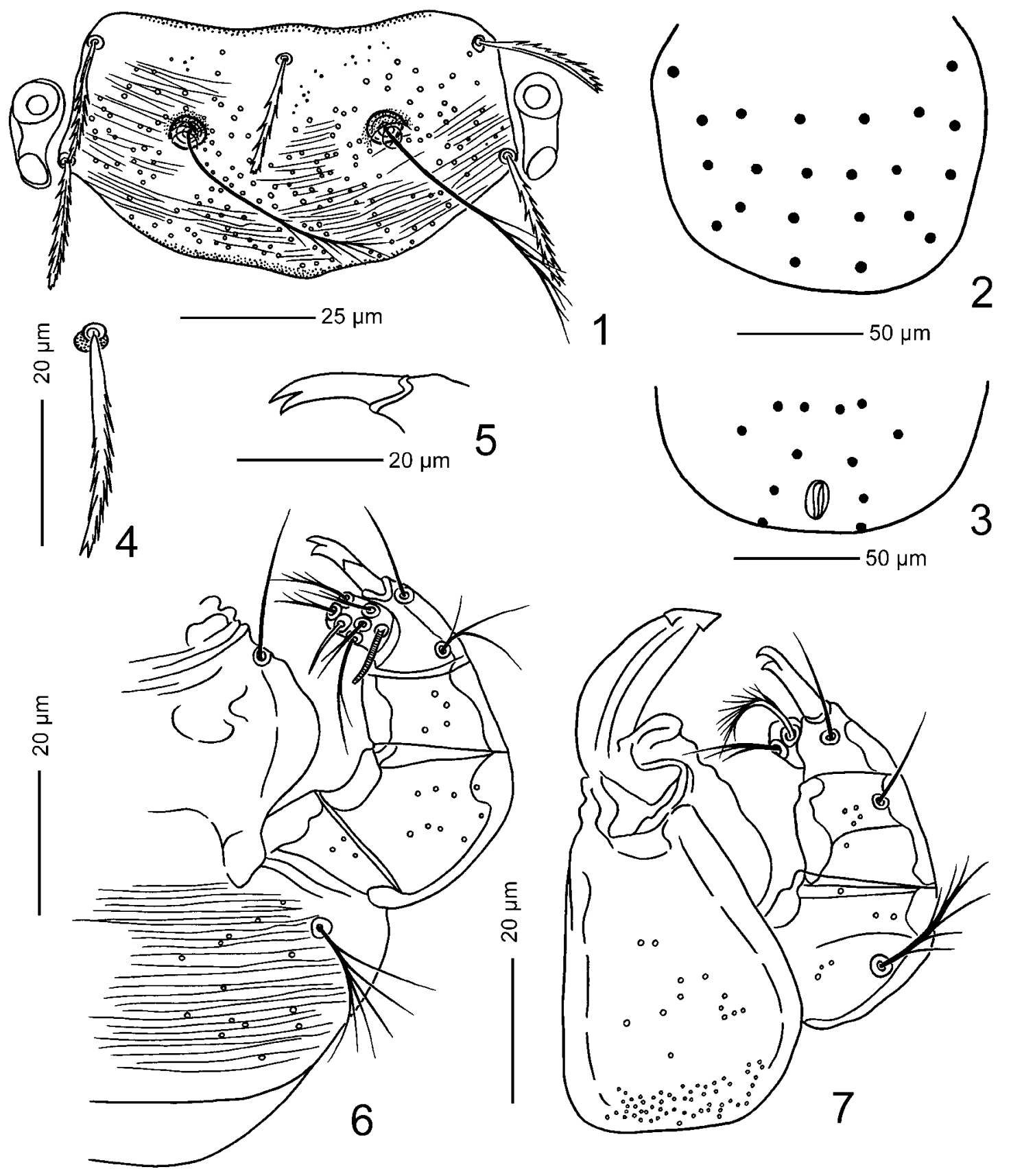

Figs. 1-7. Eutrombicula cubensis sp. n., larva. Fig. 1. Scutum and eyes. Fig. 2. Arrangement of dorsal idiosomal setae in unengorged specimen. Fig. 3. Arrangement of ventral idiosomal setae in unengorged specimen. Fig. 4. Dorsal idiosomal seta. Fig. 5. Palpal claw, lateral view. Fig. 6. Ventral aspect of gnathosoma. Fig. 7. Dorsal aspect of gnathosoma.

coxa $1 \mathrm{~B}$; trochanter $1 \mathrm{~B}$; basifemur $2 \mathrm{~B}$; telofemur $3 \mathrm{~B}$; genu 3B, genuala; tibia 6B, tibiala; tarsus 14B, mastitarsala nude or weakly branched.

Standard measurements of the type series $(n=16)$ :

\begin{tabular}{cccccccc}
\hline P-PL & AP & AM & AL & PL & S & H & D \\
\hline 20 & 21 & 21 & 22 & 24 & 44 & 25 & $21-27$ \\
17 & 19 & 21 & 20 & 24 & 40 & 25 & $19-26$ \\
22 & 27 & 26 & 25 & 32 & 50 & 35 & $30-35$ \\
19 & 24 & 23 & 22 & 29 & 45 & 31 & $25-30$ \\
\hline & & & & & & & \\
\hline V & pa & pm & pp & Ip & TaIII & TaW & m-t \\
\hline $22-27$ & 261 & 216 & 230 & 707 & 61 & 12 & 0.382 \\
$22-27$ & 256 & 207 & 230 & 700 & 58 & 11 & 0.264 \\
$23-31$ & 286 & 239 & 277 & 803 & 72 & 13 & 0.400 \\
$23-29$ & 268 & 226 & 253 & 747 & 67 & 12 & 0.320 \\
\hline
\end{tabular}




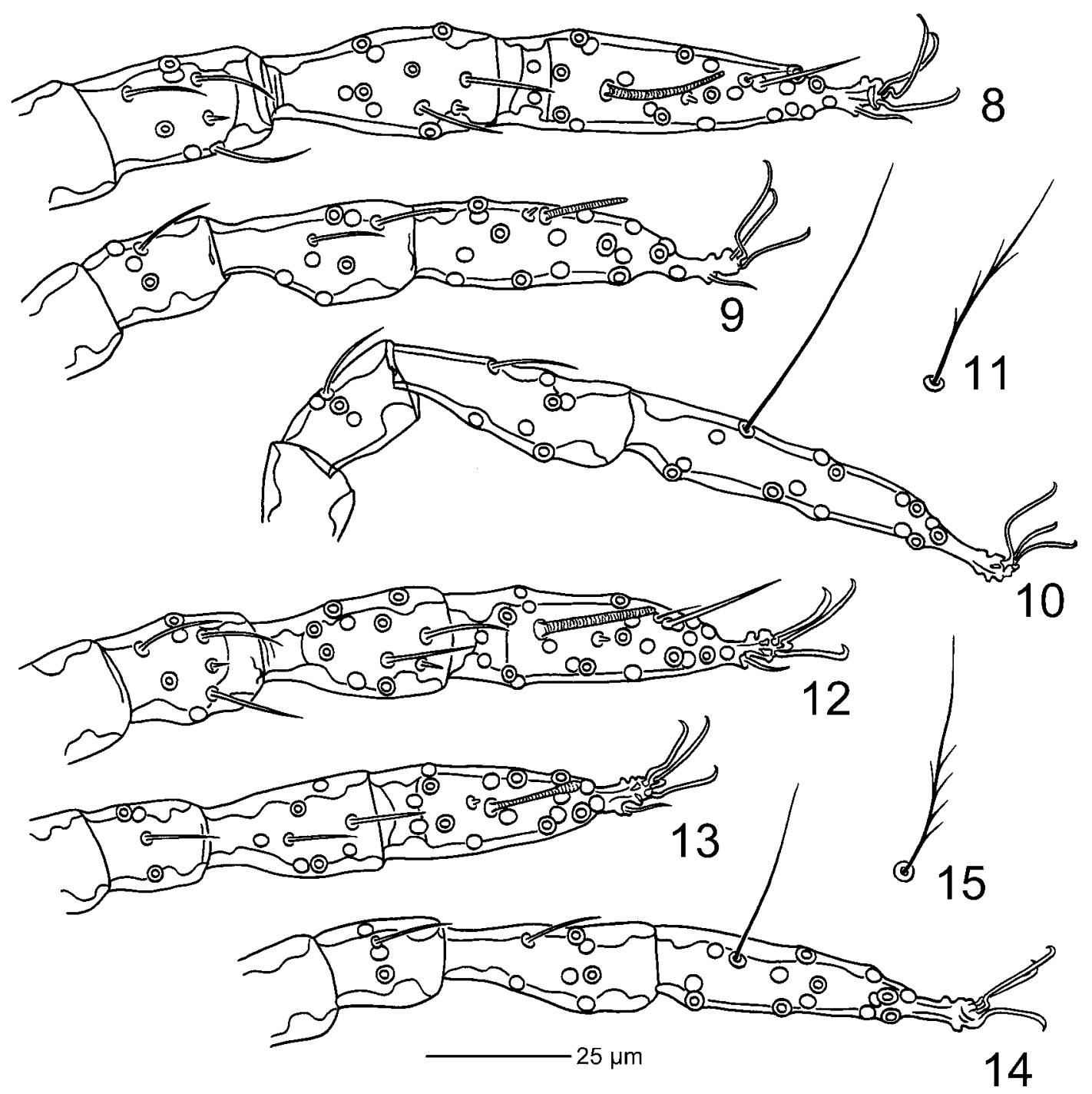

Figs. 8-11. Eutrombicula cubensis sp. n., larva. Fig. 8. Leg I. Fig. 9. Leg II. Fig. 10. Leg III. Fig. 11. Branched variant of mastitarsala. Figs. 12-15. Eutrombicula anguliscuta sp. n., larva. Fig. 12. Leg I. Fig. 13. Leg II. Fig. 14. Leg III. Fig. 15. Branched variant of mastitarsala.

H o s t s : Leiocephalus cubensis (Gray, 1840), L. macropus Cope, 1863, L. stictigaster Schwartz, 1959 (Reptilia, Squamata, Iguanidae); Ameiva auberi Cocteau, 1838 (Reptilia, Squamata, Teiidae); Pteronotus macleayii (Gray, 1839) (Mammalia, Chiroptera, Mormoopidae).

T y p e d a t a : Holotype larva (C-36, T-Tr.-22), Cayuelo de la Vela, 13 March 1965, from A. auberi. 147 paratypes: 14 larvae, same data as holotype; 4 larvae, Trinidad Province, Guaurabo, Carretera del Rio, 1 March 1965, from L. cubensis; 17 larvae, Trinidad Province, Rio Guaurabo, Ceiba de Hernan Cortez, 1 March 1965, from L. cubensis; 32 larvae, Cayo Lanzanillo, 11-12 March 1965, from A. auberi; 1 larva, Santa Cruz del Zaele, 24 March 1965, from $L$. cubensis; 2 larvae, Oriente Province, Gibara, 28 March 1965, from L. cubensis; 12 larvae, Oriente Province, Vereon, Cabo Cruz, 30 March 1965, from A. auberi and $L$. macropus; 49 larvae, Cayo Postrero, 15 Apr. 1965, from $L$. cubensis; 1 larva, Cayo Piedra, 15 Apr. 1965, from L. stic- tigaster; 9 larvae, Punta del Este, 17 Apr. 1965, from L. cubensis; 6 larvae, Sancti Spiritus Province, Cueva de Colón, 25 Apr. 1965, from P. macleayii. The holotype and 100 paratypes (nos. C-8 to C-645) are deposited in ZIN; 27 paratypes (nos. C-12 to C-633) are deposited in PaÚ (coll. no. PaÚ 1998); 20 paratypes (nos. C-27 to C-420) are deposited in the collection of the senior author.

E t y m o log y: Specific epithet refers to the terra typica.

Differential diagnosis. The new species is similar to Eutrombicula belkini (Gould, 1950) and differs from it in having $\mathrm{fD}=2 \mathrm{H}-6-6-6-2$ versus $2 \mathrm{H}-6-6-4-2$ (6-6-2-4), shorter setae (average $\mathrm{AL}=22$ versus $31, \mathrm{PL}=29$ versus 41$)$, shorter and less branched sensilla ( $\mathrm{S}=45$ versus 55 , sensilla with 7-8 branches versus 10-14), tarsala I 19-22 long versus 10-12 according to Wolfenbarger (1953), mastitarsala frequently nude versus always branched and palpal genual seta always nude versus frequently branched. 


\section{Eutrombicula anguliscuta sp. $\mathrm{n}$.}

Figs. 12-21

Diagnosis. SIF $=7 \mathrm{BS}-\mathrm{N}-2-3111.1000 ; \mathrm{fPp}=\mathrm{B} / \mathrm{B} /$ $\mathrm{NNN} ; \mathrm{fCx}=1.1 .1 ; \mathrm{fSt}=2.2 ; \mathrm{fSc}: \mathrm{PL}>\mathrm{AM}>\mathrm{AL} ; \mathrm{Ip}=$ $678 ; \mathrm{fD}=2 \mathrm{H}-6-6-2-4 ; \mathrm{fV}=6-2-2-2 ; \mathrm{DS}=20 ; \mathrm{VS}=12$; $\mathrm{NDV}=32$.

Description. LARVA. Idiosoma. Eyes $2+2$. One pair of humeral setae; 18 dorsal idiosomal setae, arranged 66-2-4 (6-6-4-2); 2 pairs of sternal setae and 12 ventral setae, arranged 6-2-2-2; total idiosomal setae 32 . Gnathosoma. Cheliceral blade with tricuspid cap; cheliceral base with dense small puncta in basal part and few large puncta in middle portion; gnathobase with sparse puncta, without transverse striations, bearing a pair of branched setae; palpal femur and genu with few puncta; galeala nude; palpal claw with 2 equal prongs or inner prong somewhat larger; setae on palpal femur and genu weakly branched; all palpal tibial setae nude; palpal tarsus with strongly branched dorsal seta, moderately branched lateral seta and 5 weakly branched ventral setae, nude subterminala and tarsala. Scutum. Nearly pentagonal, with angulate posterior margin and sparse puncta, without transverse striations; AM base on level of ALs; SB anterior to level of PLs; PL $>A M>A L$; sensilla flagelliform with 6-7 branches in distal half. Legs. All 7-segmented, with a pair of claws and clawlike empodium. Leg I: coxa $1 \mathrm{~B}$; trochanter 1B; basifemur 1B; telofemur 5B; genu 4B, 3 genualae, microgenuala; tibia 8B, 2 tibialae, microtibiala; tarsus 22B, tarsala 15-20 (18) long, microtarsala, subterminala, parasubterminala, pretarsala. Leg II: coxa $1 \mathrm{~B}$; trochanter 1B; basifemur 2B; telofemur $4 \mathrm{~B}$; genu $3 \mathrm{~B}$, genuala; tibia 6B, 2 tibialae; tarsus 16B, tarsala 14-16 (15) long, with inflated apex, microtarsala, pretarsala. Leg III: coxa $1 \mathrm{~B}$; trochanter $1 \mathrm{~B}$; basifemur $2 \mathrm{~B}$; telofemur $3 \mathrm{~B}$; genu $3 \mathrm{~B}$, genuala; tibia $6 \mathrm{~B}$, tibiala; tarsus $14 \mathrm{~B}$, mastitarsala nude or branched.

Standard measurements of the type series $(n=15)$ :

\begin{tabular}{l|cccccc}
\hline & AW & PW & SB & ASB & PSB & SD \\
\hline Holotype & 65 & 74 & 36 & 23 & 25 & 48 \\
Minimum & 59 & 70 & 33 & 17 & 23 & 42 \\
Maximum & 68 & 82 & 38 & 23 & 29 & 51 \\
Mean & 64 & 75 & 36 & 20 & 26 & 46 \\
\hline
\end{tabular}

\begin{tabular}{cccccccc}
\hline P-PL & AP & AM & AL & PL & H & D & V \\
\hline 20 & 22 & 25 & 22 & 36 & 33 & $28-34$ & $25-31$ \\
16 & 19 & 21 & 18 & 29 & 29 & $23-29$ & $23-25$ \\
20 & 25 & 25 & 23 & 41 & 38 & $31-36$ & $28-33$ \\
19 & 22 & 23 & 21 & 35 & 33 & $26-33$ & $25-30$ \\
\hline \multicolumn{1}{r}{} & \multicolumn{1}{c}{ pm } & pp & Ip & TaIII & TaW & m-t \\
\hline 245 & 211 & 239 & 695 & 61 & 12 & 0.309 \\
220 & 178 & 218 & 616 & 50 & 11 & 0.239 \\
256 & 227 & 245 & 722 & 61 & 14 & 0.359 \\
239 & 206 & 232 & 678 & 57 & 12 & 0.314 \\
\hline
\end{tabular}

H o s t s: Anolis bartschi (Cochran, 1928), A. chamaeleonides Dumeril et Bibron, 1837, A. equestris Merrem, 1820, Norops sagrei (Dumeril et Bibron, 1837), Leiocephalus cubensis, L. macropus, L. stictigaster (Reptilia, Squamata,
Iguanidae); Natalus lepidus (Gervais, 1837) (Mammalia, Chiroptera, Natalidae); P. macleayii (Mammalia, Chiroptera, Mormoopidae).

T y p e d a t a : Holotype larva (C-221, T-Tr.-24), Cayo Postrero, 15 Apr. 1965, from L. cubensis. 63 paratypes: 9 larvae, same data as holotype; 4 larvae, Zapata, Camino de Santo Tomas (between Santo Tomas and Playa Larga), 26 Feb. 1965, from A. chamaeleonides; 1 larva, Zapata, Santo Tomas, 26 Feb. 1965, from N. sagrei; 8 larvae, Oriente Province, Vereon, Cabo Cruz, 30 March 1965, from $N$. sagrei and L. macropus; 24 larvae, Cayo Piedra, 15 Apr. 1965, from L. stictigaster; 1 larva, Siguanea, 16 Apr. 1965, from L. cubensis; 8 larvae, Punta del Este, 17 Apr. 1965, from L. cubensis; 1 larva, Pinar del Rio Province, Viñales, Valle de San Vincente, 20 Aug. 1965, from A. bartschi; 4 larvae, Carapachibey, 18 Apr. 1965, from A. equestris; 1 larva, Sancti Spiritus Province, Cueva de Colón, 25 Apr. 1965, from P. macleayii; 2 larvae, La Habana Province, Guanajay, Cueva de William Palmer, 12 Aug. 1965, from $N$. lepidus. The holotype and 33 paratypes (nos. C-1 to C655 ) are deposited in ZIN; 15 paratypes (nos. C-2 to C652) are deposited in PaÚ (coll. no. PaÚ 1999); 15 paratypes (nos. C-62 to C-654) are deposited in the collection of the senior author.

E t y m o 1 o g y : Specific epithet refers to the angulate posterior margin of the scutum.

Differential diagnosis. The new species differs from all other Eutrombicula species in having an angulate posterior margin of the scutum, which is characteristic of the genus Neotrombicula Hirst, 1925. It is most similar to E. belkini and differs from this species, in addition to the above character, in having a nude ventral palpal tibial seta, less branched sensilla (6-7 branches versus 10-14), much longer tarsala I (15-20 versus 10-12) and absence of striations on the scutum and gnathobase.

\section{Eutrombicula leiocephali sp. $\mathrm{n}$.}

Figs. 22-29

Diagnosis. $\mathrm{SIF}=7 \mathrm{BS}-\mathrm{N}-2-3111.1000 ; \mathrm{fPp}=\mathrm{B} / \mathrm{B} /$ $\mathrm{NNB} ; \mathrm{fCx}=1.1 .1 ; \mathrm{fSt}=2.2$; $\mathrm{fSc}: \mathrm{PL}>\mathrm{AM}>\mathrm{AL} ; \mathrm{Ip}=$ 692; $\mathrm{fD}=2 \mathrm{H}-6-6-6-2$ or $2 \mathrm{H}-6-6-2-4 ; \mathrm{fV}=6-2-2-2$; DS $=22$ or $20 ; \mathrm{VS}=12 ; \mathrm{NDV}=34$ or 32 .

Description. LARVA. Idiosoma. Eyes 2+2. One pair of humeral setae; 20 dorsal idiosomal setae, arranged 66-6-2, or 18 dorsal idiosomal setae, arranged 6-6-2-4 (in $25 \%$ of specimens examined); 2 pairs of sternal setae and 12 ventral setae, arranged 6-2-2-2; total idiosomal setae 34 or 32 (34 in holotype). Gnathosoma. Cheliceral blade with tricuspid cap; cheliceral base and palpi not punctate; gnathobase with few puncta and transverse striations, bearing a pair of branched setae; galeala nude; palpal claw 2-pronged, the outer prong much more larger; setae on palpal femur and genu weakly branched; dorsal and lateral palpal tibial setae nude, ventral palpal tibial seta with few branches; palpal tarsus with 7 weakly branched setae, nude subterminala and tarsala. Scutum. Nearly rectangular, with rounded posterior margin, sparse puncta of different size, and indistinct transverse striations; AM base on level of 

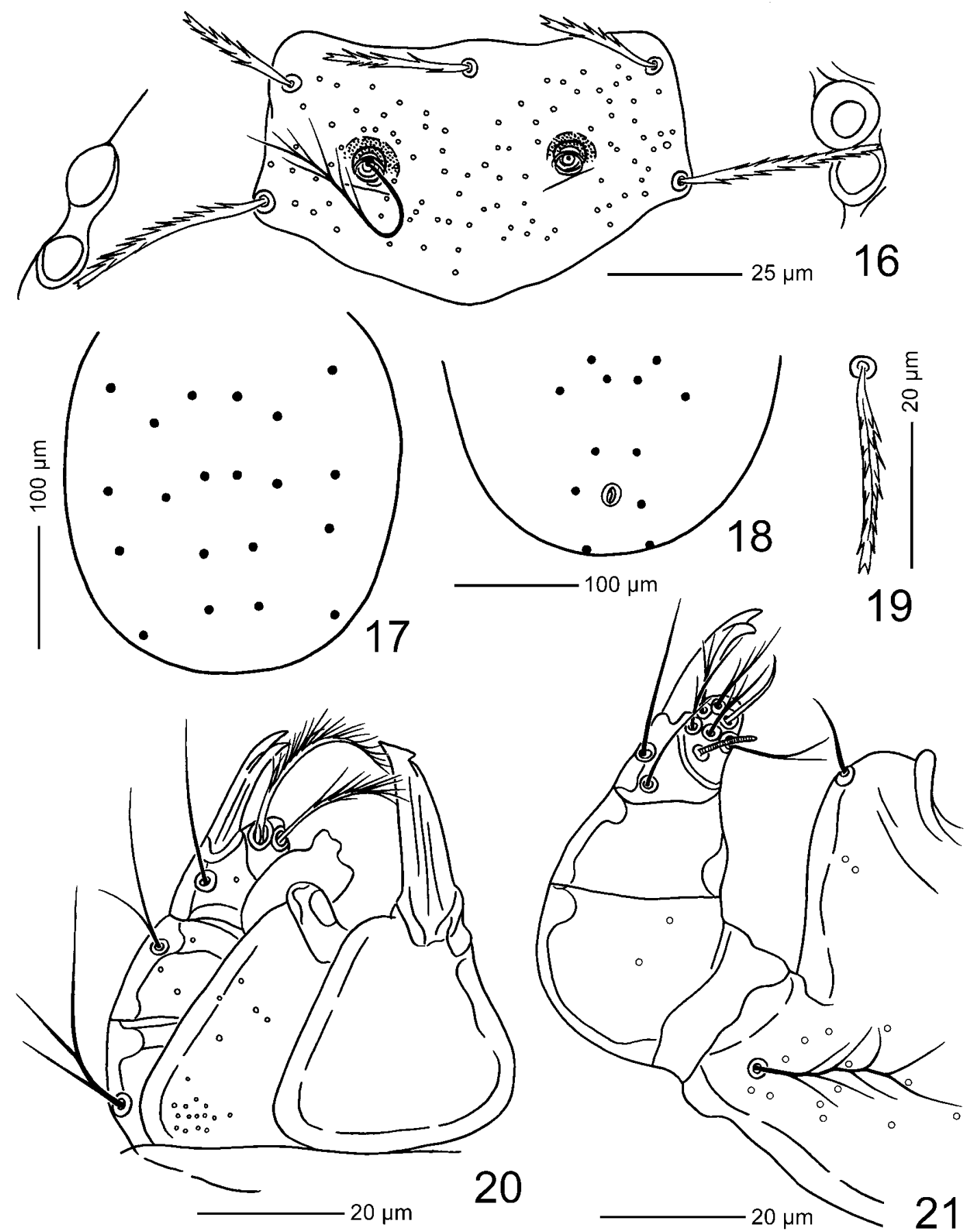

Figs. 16-21. Eutrombicula anguliscuta sp. n., larva. Fig. 16. Scutum and eyes. Fig. 17. Arrangement of dorsal idiosomal setae in engorged specimen. Fig. 18. Arrangement of ventral idiosomal setae in engorged specimen. Fig. 19. Dorsal idiosomal seta. Fig. 20. Dorsal aspect of gnathosoma. Fig. 21. Ventral aspect of gnathosoma.

ALs; SB anterior to level of PLs; PL $>$ AM $>$ AL; sensilla flagelliform with 9-11 branches in distal half. Legs. All 7-segmented, with a pair of claws and clawlike empodium. Leg I: coxa 1B; trochanter 1B; basifemur 1B; telofemur 5B; genu 4B, 3 genualae, microgenuala; tibia $8 \mathrm{~B}, 2$ tibialae, microtibiala; tarsus 22B, tarsala 17-24 (20) long, microtarsala, subterminala, parasubtermi- nala, pretarsala. Leg II: coxa $1 \mathrm{~B}$; trochanter $1 \mathrm{~B}$; basifemur $2 \mathrm{~B}$; telofemur $4 \mathrm{~B}$; genu $3 \mathrm{~B}$, genuala; tibia $6 \mathrm{~B}, 2$ tibialae; tarsus 16B, tarsala 14-18 (15) long, with inflated apex, microtarsala, pretarsala. Leg III: coxa 1B; trochanter 1B; basifemur 2B; telofemur $3 \mathrm{~B}$; genu $3 \mathrm{~B}$, genuala; tibia $6 \mathrm{~B}$, tibiala; tarsus $14 \mathrm{~B}$, mastitarsala almost nude or branched. 

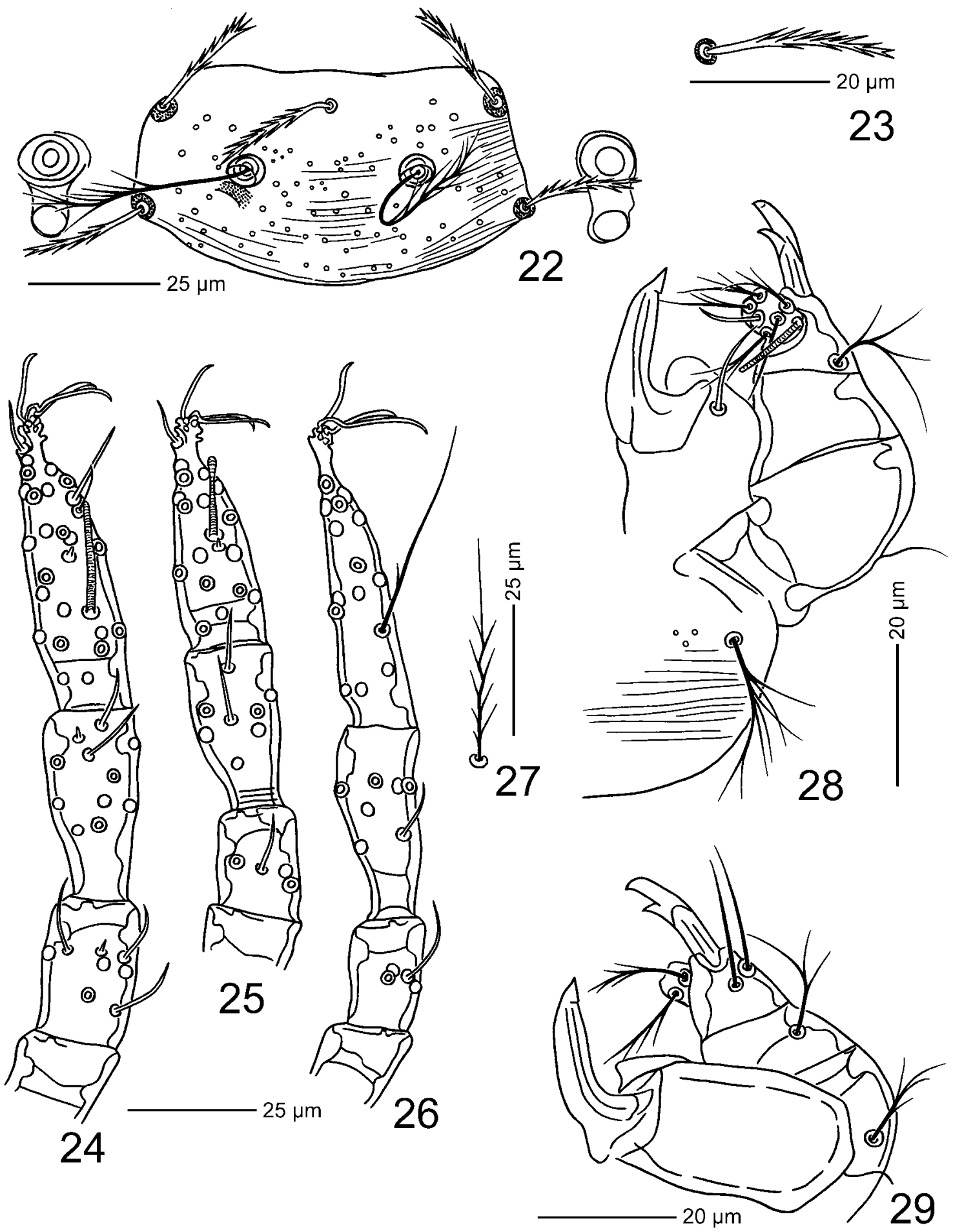

Figs. 22-29. Eutrombicula leiocephali sp. n., larva. Fig. 22. Scutum and eyes. Fig. 23. Dorsal idiosomal seta. Fig. 24. Leg I. Fig. 25. Leg II. Fig. 26. Leg III. Fig. 27. Branched variant of mastitarsala. Fig. 28. Ventral aspect of gnathosoma. Fig. 29. Dorsal aspect of gnathosoma. 
Standard measurements of the type series $(n=16)$ :

\begin{tabular}{|c|c|c|c|c|c|c|c|c|}
\hline & AW & PW & SB & ASB & PSB & SD & P-PL \\
\hline \multicolumn{2}{|c|}{ Holotype } & 62 & 75 & 35 & 20 & 22 & 42 & 14 \\
\hline \multicolumn{2}{|c|}{ Minimum } & 60 & 70 & 30 & 19 & 20 & 40 & 12 \\
\hline \multicolumn{2}{|c|}{ Maximum } & 67 & 81 & 37 & 23 & 24 & 45 & 18 \\
\hline \multicolumn{2}{|c|}{ Mean } & 63 & 76 & 34 & 20 & 22 & 42 & 15 \\
\hline AP & $\mathrm{AM}$ & $\mathrm{AL}$ & PL & $\mathrm{H}$ & $\mathrm{D}$ & $\mathrm{V}$ & pa & $\mathrm{pm}$ \\
\hline 22 & 25 & 22 & 27 & 31 & $24-32$ & $23-32$ & 245 & 212 \\
\hline 19 & 22 & 20 & 22 & 26 & $18-25$ & $19-30$ & 229 & 202 \\
\hline 24 & 27 & 24 & 32 & 35 & $27-33$ & $25-32$ & 259 & 220 \\
\hline 22 & 25 & 22 & 28 & 32 & 24-30 & $23-31$ & 243 & 211 \\
\hline $\mathrm{pp}$ & Ip & $\mathrm{DS}$ & & $\mathrm{VS}$ & NDV & TaIII & TaW & $m-t$ \\
\hline 230 & 688 & 22 & & 12 & 34 & 59 & 12 & 0.333 \\
\hline 223 & 657 & 20 & & 11 & 32 & 58 & 11 & 0.297 \\
\hline 250 & 724 & 24 & & 12 & 36 & 67 & 14 & 0.382 \\
\hline 238 & 692 & 22 & & 12 & 34 & 61 & 12 & 0.337 \\
\hline
\end{tabular}

H o s t s : Leiocephalus carinatus (Gray, 1827), L. macropus, L. raviceps Cope, 1863 (Reptilia, Squamata, Iguanidae).

T y p e d a t a : Holotype larva (C-402, T-Tr.-23), Santiago de Cuba, Ciudamar, 20 Sept. 1965, from L. carinatus. 42 paratypes: 22 larvae, same data as holotype; 10 larvae, Oriente Province, Vereon, Cabo Cruz, 30 March 1965, from L. macropus and L. carinatus; 10 larvae, Oriente Province, Baitiquiri, 1 Apr. 1965, from L. raviceps. The holotype and 22 paratypes (nos. C-88 to C-414) are deposited in ZIN; 10 paratypes (nos. C-106 to C-413) are deposited in PaÚ (coll. no. PaÚ 2000); 10 paratypes (nos. C-104 to C-401) are deposited in the collection of the senior author.

E t y m o 1 o g y : Specific epithet derives from the generic name of the hosts.

Differential diagnosis. The new species is similar to E. cubensis and differs from it in a branched palpal genual seta, palpal claw with the outer prong much more larger than the inner prong, tarsala II with inflated apex, punctation of scutum and gnathosoma more sparse, scutum shorter (PSB $=20-24$ versus 23-29, P$\mathrm{PL}=12-18$ versus $17-22, \mathrm{SD}=40-45$ versus $45-52$ ) and legs shorter $(\mathrm{Ip}=657-724$ versus 700-803).

Remarks. Variation of $\mathrm{fD}$ in this species is unusual for the chiggers having so few idiosomal setae. Probably, E. leiocephali is identical with the unnamed species of Eutrombicula reported from Cuba by Dusbábek (1970). According to this author, his species resembles E. belkini, but differs in another form of posterior scutal margin and palpal claw as in E. goeldii (Oudemans, 1910) (the latter has a palpal claw with a long stout outer prong and a short inner prong). But possible host specificity of E. leiocephali (which was found at the time on lizards of the genus Leiocephalus only) is against this supposition, since the material studied by Dusbábek was collected on a host from another class, Capromys pilorides (Say, 1822) (Mammalia, Rodentia, Capromyidae). Unfortunately, the author did not give a complete morphological description of the species.
Eutrombicula alfreddugesi (Oudemans, 1910)

Standard measurements $(n=6)$ :

\begin{tabular}{|c|c|c|c|c|c|c|}
\hline & $\mathrm{AW}$ & $\mathrm{PW}$ & SB & ASB & PSB & SD \\
\hline Minimum & 73 & 86 & 41 & 23 & 30 & 56 \\
\hline Maximum & 78 & 91 & 46 & 26 & 33 & 59 \\
\hline Mean & 77 & 90 & 43 & 25 & 32 & 57 \\
\hline P-PL & AP & $\mathrm{AM}$ & $\mathrm{AL}$ & PL & $\mathrm{H}$ & D \\
\hline 20 & 25 & 30 & 29 & 34 & 35 & $27-35$ \\
\hline 23 & 31 & 33 & 34 & 39 & 41 & $30-38$ \\
\hline 21 & 28 & 31 & 32 & 37 & 39 & $29-36$ \\
\hline pa & $\mathrm{pm}$ & $\mathrm{pp}$ & Ip & TaIII & TaW & $\mathrm{m}-\mathrm{t}$ \\
\hline 288 & 247 & 279 & 815 & 70 & 14 & 0.256 \\
\hline 311 & 279 & 306 & 896 & 77 & 15 & 0.275 \\
\hline 298 & 261 & 288 & 847 & 73 & 14 & 0.264 \\
\hline
\end{tabular}

H o s t s : Many species of reptiles, mammals, birds, amphibians and also human.

$\mathrm{D}$ i s t r i b u t i o $\mathrm{n}$ : Throughout the American continent from southern Canada to Argentina, Caribbean Islands.

M a t e r i a 1 e x a m i n e d : 9 larvae, Cayo Postrero, 15 Apr. 1965, from Leiocephalus cubensis; 11 larvae, Cayo Piedra, 15 Apr. 1965, from L. stictigaster.

Remarks. E. alfreddugesi is the only species of the genus Eutrombicula previously reported from Cuba (de la Cruz and Abreu 1986, de la Cruz and Daniel 1994). But all data concerning findings of this species should be verified, since literary faunistic records of $E$. alfreddugesi include many cases of misidentification (Loomis and Wrenn 1984). According to our data, E. alfreddugesi is a rather rare species in Cuba, as compared with E. cubensis and E. anguliscuta.

Eutrombicula lipovskyana (Wolfenbarger, 1953)

Standard measurements $(n=7)$ :

\begin{tabular}{|c|c|c|c|c|c|c|}
\hline & AW & PW & SB & ASB & PSB & SD \\
\hline Minimum & 76 & 87 & 40 & 25 & 28 & 54 \\
\hline Maximum & 86 & 98 & 44 & 32 & 35 & 65 \\
\hline Mean & 81 & 94 & 43 & 28 & 31 & 59 \\
\hline P-PL & AP & $\mathrm{AM}$ & $\mathrm{AL}$ & $\mathrm{PL}$ & $\mathrm{H}$ & $\mathrm{D}$ \\
\hline 18 & 27 & 31 & 29 & 44 & 43 & $32-41$ \\
\hline 24 & 32 & 38 & 38 & 52 & 50 & $41-49$ \\
\hline 20 & 29 & 35 & 34 & 49 & 46 & $37-46$ \\
\hline $\mathrm{pa}$ & $\mathrm{pm}$ & $\mathrm{pp}$ & Ip & TaIII & $\mathrm{TaW}$ & $\mathrm{m}-\mathrm{t}$ \\
\hline 324 & 286 & 322 & 949 & 79 & 16 & 0.269 \\
\hline 358 & 306 & 356 & 1021 & 90 & 17 & 0.323 \\
\hline 346 & 298 & 340 & 984 & 86 & 16 & 0.304 \\
\hline
\end{tabular}

H o s t s : Many species of birds, reptiles, mammals and rarely amphibians.

D i s t r i b u t i o n : southern United States (Kansas, Tennessee, Mississippi, Louisiana, Arkansas, Oklahoma), Panama. Recorded in Cuba for the first time.

M a t e r i a 1 e x a m i n e d : 23 larvae, Zapata, Camino de Santa Tomas, 26 Feb. 1965, from Saurothera merlini Orbigny, 1839 (Aves, Cuculiformes, Cuculidae); 15 larvae, Cayo Postrero, 15 Apr. 1965, from Leiocephalus cubensis and S. merlini. 
Acknowledgements. This work was supported in part by the Grant of the President of the Russian Federation for State Support of Leading Scientific Schools (no. SS-1664.2003.4). We are grateful to Prof. D.A. Crossley, Jr. (University of Georgia,
Institute of Ecology, Athens, Georgia, USA) for the help in the preparation of the English text. We also thank two anonymous reviewers for useful comments.

\section{REFERENCES}

de la CRUZ J., ABREU R.M. 1986: El abuje o abujo, Eutrombicula alfreddugesi (Acarina: Trombiculidae), un ácaro de importancia biomédica en las provincias orientales de Cuba. Rev. Cubana Med. Trop. 38: 119-125.

de la CRUZ J., DANIEL M. 1994: Chigger mites (Acarina: Leeuwenhoekiidae) from Cuba. Folia Parasitol. 41: 71-74.

DUSBÁBEK F. 1970: New records of parasitic mites (Acarina) from Cuba and Mexico. Mitt. Zool. Mus. Berlin 46: $273-276$.

Received 4 November 2003
GOFF M.L., LOOMIS R.B., WELBOURN W.C., WRENN W.J. 1982: A glossary of chigger terminology (Acari: Trombiculidae). J. Med. Entomol. 19: 221-238.

LOOMIS R.B., WRENN W.J. 1984: Systematics of the pest chigger genus Eutrombicula (Acari: Trombiculidae). In: D.A. Griffiths and C.E. Bowman (Eds.), Acarology 6, Vol. 1. Ellis Horwood, Chichester, pp. 152-159.

WOLFENBARGER K.A. 1953: Systematic and biological studies on North American chiggers of the genus Trombicula, subgenus Eutrombicula (Acarina, Trombiculidae). Ann. Entomol. Soc. Am. 45: 645-677.

Accepted 4 February 2004 